УДК $811.111-161.2 ’ 347$

DOI https://doi.org/10.26661/2414-1135-2021-82-52

\title{
СТРУКТУРНІ ОСОБЛИВОСТІ АНГЛОМОВНОЇ МЕДИЧНОЇ ТЕРМІНОЛОГІЇ НА ПОЗНАЧЕННЯ КОРОНАВIРУСУ COVID-19
}

\author{
Хацер Г. О. \\ кандидат філологічних наук, доиент, \\ доцент кафедри теорії та практики перекладу з англійської мови \\ Запорізький національний університет \\ вул. Жуковського, 66, Запоріжжя, Украӥна \\ orcid.org/0000-0003-0601-5572 \\ anvann@ukr.net \\ Жаворонкова В. В. \\ викладач кафедри іноземних мов \\ Запорізький державний медичний університет \\ пр. Маяковського, 26, Запоріжжя, Україна \\ orcid.org/0000-0001-5987-4704 \\ zhav.vika@gmail.com
}

\begin{abstract}
Ключові слова: англомовна медична термінологія на позначення коронавірусу COVID-19, термінисловосполучення, похідні терміни, терміниабревіатури, складні терміни, прості терміни.
\end{abstract}

Статтю присвячено проблемі формування англомовної медичної термінології на позначення пандемії коронавірусу COVID-19. Акцент робиться на дослідженні організаційної структури англомовної медичної термінології на позначення коронавірусу COVID-19 та виявленні структурних особливостей термінологічних одиниць, що входять до кожної з груп. Окреслено причини, які зумовили нагальну потребу в дослідженні цього виду медичної термінології. У процесі дослідження надана кластерна структура англомовних медичних термінів на позначення коронавірусу COVID-19 (AMTK-19), до якої належать: Therapeutic and General Terms / Терапевтичні та загальні терміни; Case and Symptoms Terms / Терміни на позначення захворювання та його ознак; Quarantine, Protection and Isolation Measures Terms / Терміни на позначення карантинних та ізоляційних заходів; Medical Equipment and Medicine Terms / Терміни на позначення медичного обладнання та ліків; Testing terms / Терміни тестування. Виявлено, що головними способами формування АМТК-19 є синтаксичний та морфологічний. Усі термінологічні одиниці, що досліджувалися, можна поділити на: термінисловосполучення, похідні терміни (деривати), терміни-абревіатури, складні й прості терміни. Найпродуктивнішою групою $є$ термінисловосполучення, що пояснюється прагненням розширити та надати більш розгорнуте лексичне значення явищу чи предмету, що позначається. Виявлено, що найбільша кількість термінів-словосполучень належить до кластерів «Терапевтичні та загальні терміни» й «Терміни тестування». Під час аналізу частиномовного вираження складників ТС установлено домінування структур Adj+N та N+N. Похідні АМТК-19 мають тенденцію до утворення суфіксальним або префіксальним способами. Окремо пояснюється значна кількість ініціальних термінів-абревіатур у АМТК-19 3 переважанням у кластерах «Терміни на позначення захворювання та його ознак» та «Терміни на позначення медичного обладнання та ліків». Виявлено їх номінативний характер (називання явищ або предметів). Дослідження показало, що прості й складні терміни АМТК-19 не $є$ численними й використовуються для найменування засобів захисту, захворювання та окремих його виявів, а також медичних маніпуляцій. 
STRUCTURAL PECULIARITIES OF ENGLISH MEDICAL TERMS

ON DENOTING COVID-19

\author{
Khatser G. O. \\ Candidate of Philological Sciences, Associate Professor, \\ Associate Professor at the Department of English Translation Theory and Practice \\ Zaporizhzhia National University \\ Zhukovskoho str., 66, Zaporizhzhia, Ukraine \\ orcid.org/0000-0003-0601-5572 \\ anvann@ukr.net \\ Zhavoronkova V. V. \\ Lecturer at the Department of Foreign Languages \\ Zaporizhzhia State Medical University \\ Mayakovkii avenue, 26, Zaporizhzhia, Ukraine \\ orcid.org/0000-0001-5987-4704 \\ zhav.vika@gmail.com
}

Key words: English medical terms on denoting COVID-19, terms-combinations, derivatives, terms-abbreviations, complex terms, simple terms.

\begin{abstract}
The article deals with the problems on the formation of English medical terms on denoting COVOD-19. The emphasis is done on the identification of the organizational structure of English medical terms on denoting COVID-19 (EMRC-19) as well as the discovery of structural features of terminological units forming this type of medical terms. The article has outlined causes, which led to the topicality of scientific research of EMRC-19. The study has also provided cluster organization of EMRC-19, which consists of five groups: Therapeutic and General Terms; Case and Symptoms Terms; Quarantine, Protection, and Isolation Measures Terms; Medical Equipment and Medicine Terms; and Testing terms. The main ways to create EMRC-19 are syntactic and morphological. All terminological units under consideration can be divided into several groups: terms-combinations; derivatives terms; termsabbreviations; complex and simple terms. The most productive group is terms-combinations. It is explained by the tendency to widen and provide the most detailed lexical meaning of a phenomenon or a subject, which is being determined. In addition, the research has identified that the greatest amount of terms-combinations belongs to the following clusters: "Therapeutic and General Terms" and "Testing Terms." While analyzing parts of speech of termscombinations, dominance of $\mathrm{Adj}+\mathrm{N}$ and $\mathrm{N}+\mathrm{N}$ structures has been detected. Multicomponent terms-combinations are rarely found among EMRC-19. Derivatives medical terms on denoting COVID-19 have the tendency to being formed by suffixation and prefixation. The most popular prefixes are self- and anti-. Besides, the article has explained the reasons why terms-abbreviations are so numerous in EMRC-19, especially in clusters "Case and Symptoms Terms" and "Medical Equipment and Medicine Terms". Their nominative character (the nomination of a phenomenon or a subject) has been proven. Moreover, the study has shown that simple and complex terms of EMRC-19 are not numerous and are only used to name means of protection, cases, and their particular features as well as medical manipulations. Complex terms of EMRC-9 are characterized by semantic and structural unity.
\end{abstract}

Починаючи з грудня 2019 року, коли вперше 3'явилися ознаки нового інфекційного захворювання COVID-19, спричиненого коронавірусом SARS-CoV-2, медична та суміжні 3 нею галузі стали особливо актуальними. Учені та медичні працівники зі всього світу намагаються детально дослідити особливості захворювання, його перебіг, процеси одужання та реабілітації. Це призводить 
до розширення та збагачення термінологічного складу англомовної медичної термінології, появи нового термінологічного пласту на позначення саме коронавірусу COVID-19, який потребує детального лінгвістичного аналізу. Світові науковці приділили особливу увагу: 1) впливу COVID-19 на лексичні характеристики різних мов (арабської, української та інших) [1]; 2) появі неологізмів у системах різних мов $[2 ; 3 ; 4]$; 3) загальним характеристикам термінології COVID-19 [5; 6; 7]; 4) лінгвістичним методам дослідження поняття COVID-19 [8]. Крім цього, у центрі уваги дослідників перебуває медичний аспект появи та розповсюдження захворювання; вплив COVID-19 на суспільне життя та зміни у психологічно-емоційному стані суспільства $[9 ; 10]$. Проте проблемі структурного аналізу англомовної термінології на позначення коронавірусу COVID-19 не приділено достатньо уваги. Так, метою дослідження $є$ виявлення структурних особливостей англомовної медичної термінології на позначення коронавірусу COVID-19. Для досягнення поставленої мети необхідно розв'язати такі завдання: розглянути термінологічну систему COVID-19 як цілісне утворення, виявити структурні групи та їх кількісне відношення, дослідити особливості творення кожної групи англомовних термінів на позначення коронавірусу COVID-19. Об'скт дослідження - англомовна медична термінологія. Предмет - англомовна медична термінологія на позначення коронавірусу COVID-19

Матеріалом дослідження $€$ термінологічний корпус на позначення коронавірусу COVID-19, наданий термінологічною базою даних WIPO Pearl.

Методи та методики дослідження. Оскільки дослідження має дескриптивний характер, то у процесі аналізу використовувалися: методи суцільної вибірки для селекції фактичного матеріалу; корпусний кількісний аналіз для підрахунку фактичного матеріалу; порівняльний аналіз різних структурних груп термінології на позначення коронавірусу COVID-19, елементи статистичного аналізу для порівняння показників різних структурних елементів та частоти їх використання у термінологічному корпусі, що досліджується; описовий метод для надання інформації за кожною структурною групою термінів.

Результати та дискусії. Головними способами утворення нових термінів лінгвісти вважають семантичний, синтаксичний та морфологічний $[11 ; 12 ; 13]$. Сучасна англомовна медична термінологія на позначення коронавірусу COVID-19 має тенденцію до утворення термінів синтаксичним або морфологічним шляхом.

Термінологічна база даних WIPO Pearl (Bcecвітня організація інтелектуальної власності) додала понад 1200 нових термінологічних одиниць на позначення понять, що належать до панде- мії COVID-19, які були виокремлені та досліджені спеціалістами організації та співробітниками 3 Оклендського університету технологій (The University of Auckland), Нова Зеландія. Оскільки нині це один із найбільших та найновіших банків термінів, пов'язаних із COVID-19, то матеріалом для дослідження слугували 1200 одиниць із цієї бази даних. Розробники електронного словника виокремили 6 кластерів термінів, що належать до таких предметів, як Біологія, Діагностичне обладнання та процедури, Медичне обладнання, Патології, Охорона здоров'я та гігієна, Терапевтичні терміни. Проте автори дотримуються точки зору, що 3 появою нового напряму в медицині або нового типу захворювань 3'являються неологізми на позначення саме цих явищ та процесів. Крім того, відбувається зрушення у значенні наявних термінів, зміна їх конотації, що приводить до їх переміщення в інше термінологічне поле. Отож, термінологічні одиниці на позначення пандемії коронавірусу COVID-19 у роботі умовно поділені на п'ять груп залежно від їх змістовного навантаження та особливостей використання під час усного та письмового спілкування (рис. 1) як фахівцями, так і нефахівцями.

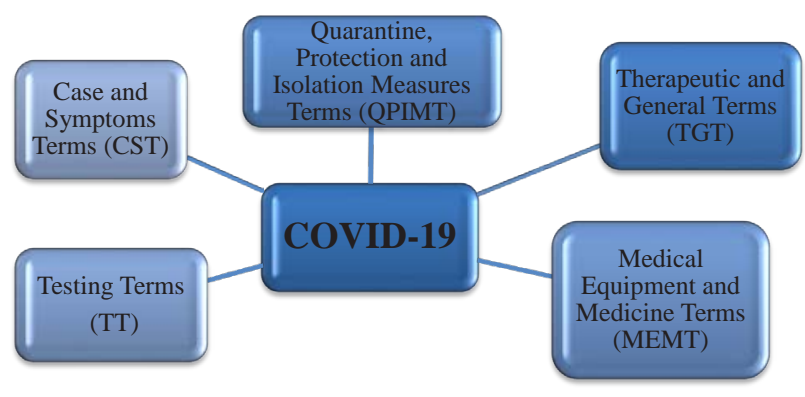

\section{Рис. 1. Кластерна структура термінологічних одиниць на позначення пандемії коронавірусу COVID-19}

До групи Therapeutic and General Terms / Tepaпевтичні та загальні терміни (ТЗТ) уналежнені всі загальномедичні та загальнотерапевтичні термінологічні одиниці: transmission, source of infection, gene therapy, vaccine. Група Case and Symptoms Terms / Терміни на позначення захворювання та його ознак (ТПЗО) містять саме терміни, характерні для пандемії коронавірусу COVID-19: historical case, casual contact, communicable, community spread. До групи Quarantine, Protection and Isolation Measures Terms / Терміни на позначення карантинних та ізоляційних заходів (ТПКІЗ) входять всі терміни, пов'язані з карантинними заходами та супутніми діями: flattening the curve, PUI (Person under investigation), quarantine at government arranged accommodation, quarantine at home (or self-quarantine) тощо. Окрему групу становлять терміни на позначення ліків, що використову- 


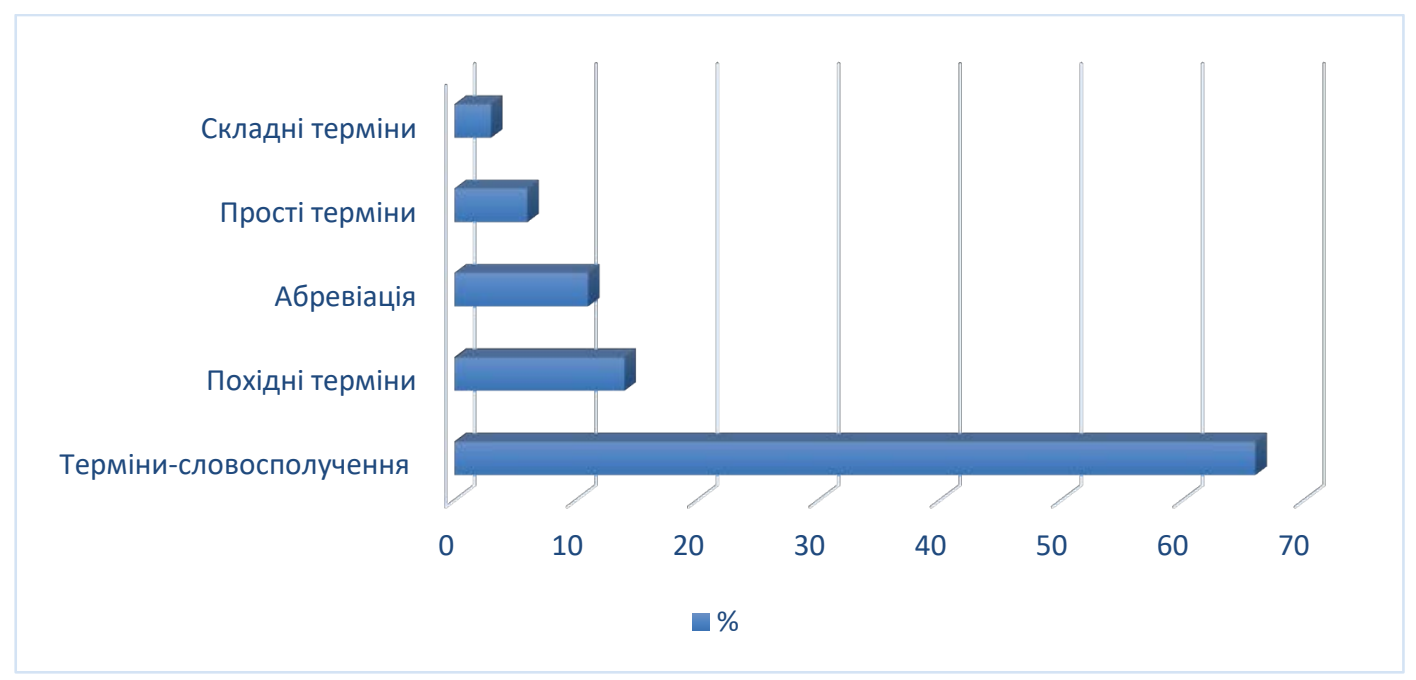

Рис. 2. Основні способи терміноутворення англомовних медичних термінів на позначення коронавірусу COVID-19

ються в роботі з хворими, медичного обладнання, яке $з$ появою пандемії набуло ургентного значення (Medical Equipment and Medicine Terms / Терміни на позначення медичного обладнання та ліків (ТМОЛ)), та терміни, що належать до процесу тестування як потенційних хворих, так і тих, хто вже захворів (Testing terms / Терміни тестування (TT)): venue check-in, drive-thru testing, outbreak/cluster, PPE (Personal protective equipment), serology testing, anti-viral medicines тощо.

Під час дослідження структурних особливостей формування англомовної медичної термінології на позначення коронавірусу COVID-19 (АМТК-19) виявлено, що вона характеризується варіативністю своїх структур. Згідно 3 рис. 2 найбільшою групою АМТК-19 є терміни-словосполучення (66\% від загальної кількості), наступними є похідні терміни (терміни-деривати) (14\%), терміни, утворені за допомогою абревіації (11\%), прості терміни (6\%) та складні терміни (3\%).

Англомовні терміни-словосполучення на позначення коронавірусу COVID-19 утворюються за допомогою приєднання одного чи декількох елементів до головного терміна. Кожен елемент додає уточнювальних характеристик, розширюючи його семантику, наприклад: presumptive positive case імовірно позитивний випадок (головний термін case, до якого додали два уточнювальні елементи у формі прикметників presumptive та positive); $s w a b$ test - до головного терміна test додано уточнювальний компонент у формі іменника swab й отримано новий термін тестування мазків.

Дві групи АМТК-19, а саме «Терапевтичні та загальні терміни» та «Терміни тестування», налічують найбільшу кількість термінів-словосполучень у загальній кількості термінів групи - 70\% та
88\% відповідно. Це пояснюється тим, що під час формування термінологічної бази коронавірусу COVID-19 за основу беруться наявні терміни із суміжних підгалузей медицини, включаючи інші види інфекційних захворювань. Крім цього, під час розроблення способів тестування саме цього захворювання використовуються загальномедичні принципи та тестування окремих виявів хвороби, що приводить до розширення лексичного значення наявних термінів. Так, якщо до загальномедичного терміна test(ing) додати скорочення $P C R$, то отримуємо вузький термін на позначення коронавірусу COVID-19 PCR testing, який називає особливий вид тестування - ПЛР-mесm.

Під час дослідження ТС на позначення коронавірусу COVID-19 виокремлено три групи: двокомпонентні (82\% від зальної кількості), трикомпонентні (17\%) та чотирикомпонентні (1\%) ТС. Що стосується частиномовного вираження складників, то найпоширенішими двокомпонентними структурами $є$ Adj+N та $\mathrm{N}+\mathrm{N}$ (рис. 3 ).

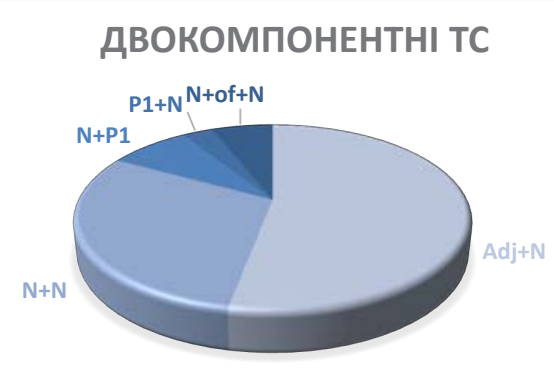

Рис. 3. Частиномовне вираження складників двокомпонентних англомовних ТС на позначення коронавірусу COVID-19 
Саме приєднання іменника або прикметника до ядра сполучення, що виражене іменником, змінює лексичне значення головного елемента та розширює його конотацію: venue check-in, respiratory droplet, spike glycoprotein, computed tomography, gene therapy, respiratory hygiene, probable case тощо.

Серед трикомпонентних ТC домінують структури $\mathrm{Adj}+\mathrm{N}+\mathrm{N}$ та $\mathrm{N}+\mathrm{N}+\mathrm{N}$ : infection fatality rate, case fatality rate, nasopharyngeal swab test, convalescent plasma therapy та інші.

Багатокомпонентні ТС у досліджуваній терміносистемі майже не трапляються. Виявлено тільки один чотирикомпонентний термін - accurate respiratory distress syndrome (гострий ресnipamopний дістрес-синдром), що пояснюється тенденцією до чіткого надання інформації без перевантаження когнітивних функцій реципієнта.

Значна кількість похідних термінів на позначення коронавірусу COVID-19 (70\% від загальної кількості) утворюється за допомогою додавання суфіксів: isolation, ventilator, epidemic, communicable, containment, mitigation тощо. Під час аналізу термінів, утворених за допомогою додавання префіксів, продуктивними виявилися такі два, як anti- та self-. Останній приєднується до основи та виконує функцію доповнення: selfisolation - staying indoors, avoiding contact with other people, and monitoring yourself for symptoms for 14 days; self-monitoring - monitoring yourself for symptoms of respiratory illness, such as fever, cough and difficulty breathing; self-quarantine voluntarily staying home if you think you are sick. Префікс anti- використовується під час опису медикаментів та дій, спрямованих на боротьбу 3 виявами коронавірусу COVID-19: antiviral (medicine or drug) - drug to treat COVID-19; antiretroviral drugs - block or slow down an enzyme that retroviruses use to chop up DNA.

За допомогою абревіації утворено 11\% термінів, що досліджуються. Достатня кількість скорочень пояснюється декількома факторами. По-перше, широким використання назв хімічних елементів, медичних термінів латинського та грецького походження. По-друге, нагальною необхідністю передати складні поняття, утворені за допомогою багатокомпонентних термінів, швидко та без смислових втрат, наприклад: mRNA-1273 - The Moderna Covid vaccine; ICU intensive care unit - a specialized department in the hospital, staffed by highly skilled physicians, nurses and more to provide care for the sickest patients; SARS-CoV-2 - severe acute respiratory syndrome coronavirus 2; MOF - multiple organ failure. Отож, найбільша кількість термінів-абревіатур спостерігається у групах «Терміни на позначення захворювання та його ознак» та «Терміни на позначення медичного обладнання та ліків» (рис. 4): PPE-personal protective equipment; RPErespiratory protective equipmen; $S A R S$ - severe acute respiratory syndrome; SIRS - systemic inflammatory response syndrome ma інші.

\section{ТЕРМІНИ-АБРЕВІАТУРИ}

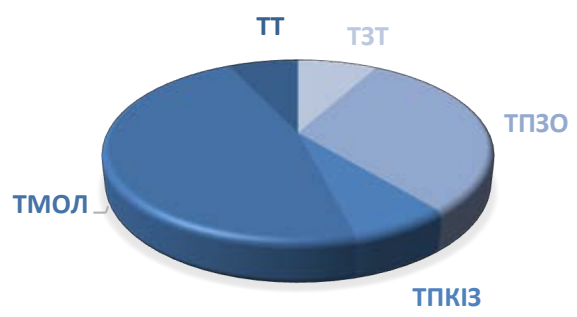

\section{Рис. 4. Розподіл термінів-абревіатур на позначення коронавірусу COVID-19 серед тематичних груп}

Як видно 3 прикладів, терміни-абревіатури фактичного матеріалу мають номінативний характер, називають явища/предмети та належать до класу іменників, тому утворюються шляхом скорочення терміносполучення до перших літер, тобто шляхом ініціалізації.

Складні та прості АТПК-19 склали найменші групи (3\% та 6\% від загальної кількості термінів відповідно). Для складних термінів характерним є семантична та структурна єдність, яка функціонує як окрема лексична одиниця. Частіше використовується структура без з'єднувального елементу: hotspot - a place where health officials have found a lot of people with COVID-19; lockdown - isolation at homes, travel restrictions, and termination of all public events to prevent the spread of COVID-19. Прості терміни виявлені у всіх групах АТПК-19 та називають хвороби, засоби захисту, медикаменти та різновиди медичних маніпуляцій. Наприклад: contact, mask, swab, host, case, virus та інші.

Висновки. Таким чином, у процесі аналізу особливостей формування англомовних термінів на позначення коронавірусу COVID-19 виявлено такі особливості:

1. Усі терміни медичної галузі, що досліджується, розподіляються на п’ять кластерів/груп залежно від їх змістовного навантаження: «Терапевтичні та загальні терміни», «Терміни на позначення захворювання та його ознак», «Терміни на позначення карантинних та ізоляційних заходів», «Терміни на позначення медичного обладнання та ліків», «Терміни тестування».

2. Найпродуктивнішим способом утворення АМТК-19 є синтаксичний (за допомогою термінів-словосполучень), що становить 66\% від загальної кількості термінів, серед яких домінують двокомпонентні англомовні терміни- 
словосполучення на позначення коронавірусу COVID-19 (82\%). Їх частиномовне вираження представлене моделями $\mathrm{Adj}+\mathrm{N}$ та $\mathrm{N}+\mathrm{N}$.

3. Похідні терміни (деривати) та терміни, утворені за допомогою абревіації, становлять $14 \%$ та $11 \%$ відповідно. Перший вид термінів утворюється суфіксальним способом. Серед префіксів домінують anti- та self-. Терміни-абревіатури частіше використовуються у групах «Терміни на позначення захворювання та його ознак» та «Терміни на позначення медичного обладнання та ліків».

4. Найменш продуктивними є способи утворення АМТК-19 за допомогою простих та складних слів. Розглядаючи структуру складних термінів, виявлено тенденцію до імплементації структур без з’єднувального елемента. Прості терміни, хоча й нечисленні, трапляються у всіх кластерах АМТК-19.

Надалі доцільно більш детально вивчити особливості використання термінів кожної групи в англомовному медичному дискурсі та проаналізувати вплив структурних особливостей АМТК-19 на їх переклад.

\section{ЛIТЕРАТУРА}

1. Ahmed H. N., Islam M. Influence of COVID-19 on the Lexical Features of English in Pakistan. Linguistics and Literature Review, 2020. I. 6 (2). P. 69-82. doi.org/10.32350/1lr.v6i2.954

2. Деркачова O.C. COVID-неологізми в системі української мови. Міждисциплінарні наукові дослідження: особливості та тендениї, 2020. Том 4. С. 73-74. doi.org/10.36074/04.12.2020.v4.12

3. Бабелюк О.А., Дідух Л.І. Способи творення неологізмів на позначення явищ covid-19 в англомовному епідеміологічному дискурсі. Львівський філологічний часопис, 2020. Випуск 7. С. 5-12.

4. Haddad A. H., Montero-Martinez S. COVID-19: a metaphor-based neologism and its translation into Arabic. JCOM, 2020. V. 19. doi. org/10.22323/2.19050201

5. Kasatkina M.S. Methods of term formation in modern English business discourse. Russian Linguistic Bulletin, 2020. I. 1 (21). P. 8-10. doi. org/10.18454/RULB.2020.21.1.29

6. Liu L, Link YH. Suggestion of Terminology in COVID-19. Arch Community Med Public Health, 2020. I. 6 (2). P. 223-224. doi: 10.17352/2455-5479.000110

7. Rafi M. S. Language of COVID-19: Discourse of Fear and Sinophobia. Social Sciences and Humanities Open, 2020. I. 6 (1). doi: 10.2139/ ssrn.3603922

8. Tan K., Woods P., Azman H., Abdullah I., et al. Covid-19 Insights and Linguistic Methods.
The Southeast Asian Journal of English Language Studies, 2020. 26(2). P. 1-23. doi. org/10.17576/3L-2020-2602-01

9. Rafi M. S. Dialogic Content Analysis of Misinformation about COVID-19 on Social Media in Pakistan. Linguistics and Literature Review, 2020. I. 6 (2). P. 129-139. doi.org/10.32350/1lr.v6i2.960

10. Worldmeter Coronavirus Update (Live): 8,931,812 Cases and 467,011 Deaths from COVID-19 Virus Pandemic Worldometer, 2020. URL: https://www.worldometers.info/ coronavirus/

11. Литвиненко Г.И. Способы словообразования как фактор системности в терминологии (на материале терминов химического машиностроения). Вісник Сумського державного університету. Серія Філологія, 2007. № 1, T. 1. C. 142-150.

12. Суперанская А.В., Подольская Н.В. Общая терминология: вопросы теории. Москва : Наука, 1989. 243 с.

13. Горкольцев Г.А. Процессы терминообразования в английском языке на примере сферы информационных технологий. Молодой ученый, 2018. № 21 (207). С. 204-206.

14. Meo S.A., Abukhalaf, A.A., Alomar, A.A. et al. Impact of lockdown on COVID-19 prevalence and mortality during 2020 pandemic: observational analysis of 27 countries. Eur J Med Res, 2020. 25 (56). /doi.org/10.1186/s40001-020-00456-9

\section{REFERENCES}

1. Ahmed, H. N., Islam, M. (2020) Influence of COVID-19 on the Lexical Features of English in Pakistan. Linguistics and Literature Review. 6(2). P. 69-82. doi.org/10.32350/11r.v6i2.954

2. Derkachova, O.S. (2020) COVID-neologisms in the system of Ukrainian [COVID-neologizmy $\mathrm{v}$ systemi ukrainskoi movy]. Interdisciplinary scientific studies: peculiarities and tendencies. V. 4, P. 73-74. doi.org/10.36074/04.12.2020.v4.12

3. Babelyuk, O.A., Didykh, L.I. (2020) Ways of translation of neologisms to denote COVID19 phenomena in English epidemiological discourse [Sposoby tvorennya neologizmiv na poznachenia yavysch covid-19 v anglomovnomu edidemiologichnomu dyskursi]. Lviv Philological Journal. I. 7: P. 5-12. doi.org/https://doi. org/10.32447/2663-340X-2020-7.1

4. Haddad, A. H., Montero-Martinez, S. (2020) COVID-19: a metaphor-based neologism and its translation into Arabic. JCOM. V. 19. doi. org/10.22323/2.19050201

5. Kasatkina, M.S. (2020) Methods of term formation in modern English business discourse. Russian Linguistic Bulletin. V. 1 (21). P. 8-10. doi.org/10.18454/RULB.2020.21.1.29 
6. Liu, L, Link, YH. (2020) Suggestion of Terminology in COVID-19. Arch Community Med Public Health. I. 6 (2). P. 223-224. doi: 10.17352/2455-5479.000110

7. Rafi, M. S. (2020) Language of COVID-19: Discourse of Fear and Sinophobia. Social Sciences and Humanities Open. doi: 10.2139/ssrn.3603922

8. Tan, K., Woods, P., Azman, H., Abdullah, I., et al. (2020) Covid-19 Insights and Linguistic Methods. The Southeast Asian Journal of English Language Studies. I. 26(2). P. 1-23. doi. org/10.17576/3L-2020-2602-01

9. Rafi, M. S. (2020) Dialogic Content Analysis of Misinformation about COVID-19 on Social Media in Pakistan. Linguistics and Literature Review. I. 6 (2). P. 129-139. doi.org/10.32350/1lr. v6i2.960
10. Worldmeter Coronavirus Update (Live): $8,931,812$ Cases and 467,011 Deaths from COVID-19 Virus Pandemic Worldometer. URL: https://www.worldometers.info/coronavirus/

11. Lytvynenko, G.I. (2007) Word-forming ways as a system factor in terminology (case study: chemical building terms) [Sposoby slovoobrazovania kak factor systemnosti v terminologii (na material terminov khimicheckogo machinostroenia]. SymDY Journal. Philology. I. 1(1). P. 161-665

12. Superankaya, A.V., Podolskaya, N.V. (2004) General terminology. M.: Nauka. 243 p.

13. Gorkoltsev, G.A. (2017) Term-creation processes in the English language (case study: IT) [Procesy terminoobrazovania $\mathrm{v}$ angliyskom yazyke na promere sfery informatsionnykh teckhnologii]. Young Scientist. I. 21(207). P. 204-206. 